821.163.41-93.09

https://doi.org/10.18485/msc.2018.47.2.ch38

Душица М. ПОТИЋ*

Висока школа струковних студија за образовање васпитача у Пироту
Оригинални научни рад

Примљен: 3. 10. 2017.

Прихваћен: 27. 12. 2017.

\title{
КАРНЕВАЛИЗАЦИЈА СЛИКЕ СВЕТА У КњИЖЕВНОСТИ ЗА ДЕЦУ
}

\begin{abstract}
Карневал је улична народна свечаност везана за време. Манифестује се у три облика: обредно-представљачке форме, књижевна смеховна и пародична дела, те различите форме и жанрови слободнијег уличног говора. Стратегије карневализације у књижевности обухватају сва три аспекта. Рад се фокусира на опште принципе карневализације слике света у српској поезији за децу, што подразумева колико прихватање готових образаца, толико њихову модификацију и прилагођавање специфичностима овог типа писма.
\end{abstract}

Кључне речи: карневализација слике света, књижевност за децу.

Намењена најмлађима, књижевност за децу је нужно једноставна. Прилагођавање интелектуалним и когнитивним могућностима детета (Марковић 1991: 5), сведеност форме, израза, садржаја, међутим, не значе аутоматски и одсуство комплексности структуре. Иако у њој преовладавају машта, хумор и игра, она може бити и више од игре, може бити мало откровење, мала драгоцена спознаја (Капичић Хаџић, 1970: 191). Сложенија него што се чини (Хант 2013: 9), није лишена ни вишезначности, што је доводи у везу с категоријом озбиљно-смешног (Курцијус 1971: 75). За категорију озбиљно-смешног везује се и карневализација књижевности (Бахтин 1978), што је и један типолошки образац књижевности за децу. Наша је претпоставка да је већини дела намењених најмлађима иманентна бар нека стратегија карневализације, што ћемо настојати да покажемо на изабраном корпусу српских песника за децу. Народна смеховна култура се манифестује у три основна облика: обредно-представљачке форме, књижевна смеховна и пародична дела те различите форме и жанрови слободнијег уличног говора. Стратегије карневализације у књижевности обухватају сва три њена аспекта, а у овом ћемо се раду усмерити на опште принципе карневализације слике света у књи-

*dusicapotic@yahoo.com 
жевности за децу. ${ }^{1}$ Одлике стратегија карневализације јесу неофицијелност и „некњижевност” - одступање од владајућег начина мишљења и његових норматива, као и несагласност књижевних слика с канонима и нормама од краја 16. века до нашег времена. Детињство се још од Коменског посматра као специфичан, издвојен феномен, који има своје законитости, другачије од оних што уређују свет одраслих (Коменски 1967). Карневал је народна светковина уличног карактера, везана је за одређено време и има сопствене законе и правила. Специфичан хронотоп, отворен, слободан простор и празнично време омогућују другачији погледа на стварност, као и најразноврсније видове и типове фантастике (Бошковић 2008: 92), што прати и дела намењена најмлађима, па и сам феномен детињства. Једно од општих места у учењима о хумору јесте да је субјективна перспектива посматрача услов без кога нема смешног. Психологија издваја изостанак критичке свести због чега дете све око себе поистовећује са собом (Пијаже, Инхелдер 1978), а његов је доживљај стварности другачији, такав да га ми прихватамо као маштовит, нерационалан, нелогичан, што је пледоаје карневалске поделе на два света. Карневал има свечовечански смисао, попут детињства није географски нити историјски условљен.

Појам народа има социјални, а не етнички карактер (Ристивојевић 2009: 29), па се и детињство може подвести под тако схваћен феномен, под издвојену заједницу која се управља према својим начелима. У том су смислу одлике карневала општенародност и универзалност. Општенародност се односи на јединственост учесника карневалске поворке, па и на доживљај те гомиле као једног тела, што конвенира дечјој потреби за припадањем групи. Типичне су у књижевности за децу дечје дружине. Једна од њих је групица јунака звана Шест вукова и један реп из истоимене поеме Бранка Ћопића. Поред карневалског ругања најмањем дечаку посредством телесног доле и игре као начина живота јунака, стратегијама карневализације припада и поигравање жанровима бајке и предања² (Ћопић 1968: 269-290). Универзалност се везује за доживљај једнакости међу људима, за укидање друштвене хијерархије, што ни детету, које тек развија социјални живот није страно. Чувена је мала бунтовница из песме „Шта је отац” (Лукић 1962: 29-31). Поред рушења табуа, карневалским стратегијама Драгана Лукића припадају метафоричка хипербола, нпр. поистовећивање оца са судијом за прекршаје, као и бесконачно, стога и смеховно претерано низање очевих поступака, дакле хуморни каталог.

Удаљеност између човека и човека укида се чином зближавања, присношћу која стоји насупрот социјалној дистанци, а одбацивање забрана и ограничења за последицу има ослобађање од страхопоштовања, од страха (Енглблом 2007: 42), што се у књижевности за децу везује и за исконски

\footnotetext{
${ }^{1}$ О другима аспектима карневализације у књижевности за децу видети: Потић 2010, Потић 2010 а, Потић 2014, Потић 2015.

2 Ове је поступке писац пак употребио и за паралелу с реалитетом и историјском стварношћу па су добили и идеолошку функцију, што би могла бити још једна тема за разматрање унутар шире проблематике карневализације.
} 
отворено урањање у свет, како Данојлић и дефинише појам наивности (Данојлић 1976). Ослобађање од страха може се односити и на фазе у развоју детета као повод да се оно охрабри или алиби да му се подсмехне. Често - и једно и друго. Ршумовић је песник овог усмерења. У песми „Ја када удахнем" све је претерано. Мали делија узима све ваздухе овоземаљске, одузима дах птицама, „стазу” авионима, да би се његова чудесна снага одразила на катастрофички поремећај широких размера: „Тако се стварају они циклони / Којих се свако паметан клони" и обрнула космички круг враћајући се човеку, враћајући се детету блиској стварности као мери његовог разумевања. Толико је велики и толико страшан кад замишља како се плаше њега. Тачније - његовог изврнутог страха (Ршумовић 1979: 18). Бројни су Змајеви ликови деце заустављени у тренуцима искушавања радости и лепота света. Песма индикативног наслова „Гојна облапорка” благо сатиричном хиперболом, коју прати позитивна емоционалност тона, афирмише виталистички принцип обликован помоћу гозбених слика: „Попила је шољу млека / Наша гојна сека; / Ал' још неће да се смири / Још у шољу вири; / Је л' остало штогод мало / На крају, у среди, / Да и то исцеди; / Две три капи - ма и више - / да и то олиже" (3мај 1989: 54). Необуздани шарениш света који се нуди очима и духу детета метафорички стаје у хуморну гастрономску приљежност јунакиње.

Општенародност и универзалност воде као утопији, али и ка сатири. Утопија је фреквентан моменат књижевности за децу, а може се довести у везу и с идеализованим схватањима детињства као златног доба човечанства (Љуштановић 2004) и позитивном онтологијом детињства (Крамбергер 2009). У Ћопићевој поеми Црвени Врабац јунаци траже „ссаrobni kraj, / Crvenog Vrapca zavičaj!” (Ћопић 1968: 428). Сивко је чуо да се тамо магарци цене и чашћавају, да живе безбрижно у „šumi najlepšeg čkalja ”. Мачак је први господар, све врви од мачјих специјалитета. Тамо чак: „, oblak ide planinom/ ogrnut, kaže, teškom slaninom.” И до пса је стигла прича какао се тамо једе славно, па и у сну. Градацијски низ претеривања од искарикиране реалистичке шуме чкаља, преко обједињавања полова горе и доле на имагинативном и гозбеном принципу идеализације, врхуни се апсурдом потеклим из народног хумора; „Onoga ko se na jelo duri / pečeni zeko po selu juri” (Ћопић 1968: 429). Логика изокретања обликује весели свет благостања и безбрижности, који се и у карневализацији и у књижевности за децу често додирује и с топосом Дембелије. Може се указати и на Ршумовићево карневалско изокретање утопије у антиутопију. У „Сонгу о земљи Дембелији”, обликованом на обрасцу антибајке, уз мотив потраге, топос пута и несрећан крај, јунак помирљиво прихвата чињеницу да Дембелија не постоји пошто је протраћио живот тражећи је (Ршумовић 1979: 69). Сатирична димензија текста посредована је иронијским еуфемизмом јер, док се привидно неутрално описује целоживотна потрага јунака, у бити се исмева његова лењост. Сатира може бити прикривена компонента књижевности за децу, премда је њена везаност за реални свет у овом типу писма више модификована ка васпитној инклинацији. Текстови овога типа увек садрже две равни, тематско-мотивску линију намењену најмлађима и димензију скривеног значења. Радовићеву пе- 
сму „Како потрошити слонове” (Радовић 2006: 42-43) обликују звучна игра риме, деци омиљен анимални лик и хумор апсурдне ситуације, али и дубоки невесели увиди у актуелну друштвену ситуацију и разорни ход историје. ${ }^{3}$ Удвојене равни моделују и текстови у којима доминира педагошка тенденција, с тим што се сатирична или иронијска позиција може и не мора експлицирати. Песма „Кад би” (Змај 1989: 89) израста из карневалски алогичног народног хумора, који се у финалном сегменту антикарневалски изокреће у пословичну поуку, у вредности официјелног света, у теновско-змајевски здрави разум. Поигравање логиком реалности и лудички хумор, као увек у бољим Змајевим песмама, одликује естетска доминација у односу на васпитне тенденције. Као и увек када педагошка и уметничка раван остану макар у тачки равнотеже.

Основно начело карневала јесте смеховно, а хумор је стални пратилац и дела намењених најмлађима. Будући иманентност без које је оно као такво немогуће, у основи поетике великог дела наше новије књижевности за децу стоји захтев за смехом (Прелевић 1979: 114). Цео свет је приказан као смешан, опажа се и поима у смеховном виду, у његовој веселој релативности. Апстрактност принципа бића у делима за најмлађе конкретизује се и географским појмовима. Како се топоними примењују и због риме, читав се глоб повезује смеховним везама, а логика рација замењена је логиком акустичких асоцијација. Црнчевић у песми „Тајна” звуковним дозивањима ниже топониме па звук постаје носилац новог, имагинарног реда: „У Лисабону на балкону пегави дечак једе бомбону." Стварност појмљена спајањем чулних сензација мора бити и чулно пренаглашен свет. Зато у Москви Гаља плаче, и с једном Гаљом једно маче. Уплашили су се јер нешто је шуштало: „А шта је шуштало? / Вече је шуштало кад се спуштало / Ето шта је шуштало”. Финални исказ иницијалну хиперболу преображава у машту, у потпуни отклон, а принцип пренаглашавања чулних сензација весели низ не успоставља на законима разума већ на законима акустике и имагинације (Црнчевић 1963: 56-58). Карневалски гозбено претеривање у песми „Шта сунце вечера” под смеховно начело подводи и космичке појаве (Данојлић 1974: 15). Карневалски смех унижава. Он негира, па и карикатурално деформише узвишено и лепо (Самарџија 2004: 8, 52). Његова бит пак није пука деструкција. Амбивалентан: весео и подругљив, негира и потврђује покопава и препорађа, обликујући веселу карневалску логику.

Уз неофицијелност, провоцирање и проверавање последњих истина, (Цар-Михец 1993) карневалски хумор одликује порицање друштвених норми и званичног система мишљења. Здрави разум је први на мети па логика изокретања проверава званичне ставове. Алогичност је фреквентна карневалска стратегија у књижевности за децу. У песми „Како живи Антутун” јунак малко необичног ума сади јаја, граби мрак лонцем, учи рибу да пева (Витез 1986: 28). Изневерава се почетно очекивање еуфемизма и на тај начин интензивира разлагање логике реалног света и обликовање смеховног, изокренутог по-

\footnotetext{
${ }^{3}$ Видети више: Потић, Јовановић 2013: 227-239.
} 
ретка. У њему је сасвим у реду радити и живети на свој начин, као што се и издвојени свет детета управља према свом. Већ је детињство по себи неофицијелно, а његово се измицање правилима додирује с просторима бесконачне слободе више него с карневалском провокацијом. У књижевности за децу нису реке ситне дечје непристојности. У песми „Ах што ја немам”: „Комшији који децу зезика / ја бих плазио седам језика”. Карневалско поигравање по себи супстандардним жаргоном прати и мотив овога типа - освета (Ршумовић 1974: 100). У песми „Шта су између осталог радили стари Словени” они су поткрадали једни друге, све до мрва заосталих после гозбе. Као деца. Карневалско уздизање недозвољеног понашања интензивира се пародијом предања и његове тежње ка истинитошћу (Данојлић 1974: 24-25). Логика изокретања, материјално-телесно начело, конкретност и чулност карневалских слика у овим се стратегијама везују за одбацивање црквених догми и ренесансно откривање човека, док у књижевности за децу оно прати и когнитивне специфичности детета, које у једној развојној фази мисли у сликама и посредством њих сазнаје стварност (Јерковић, Зотовић 2010). Оба су та аспекта карневалских стратегија у књижевности за децу лишена опсцености и непристојности и усмерена на хумор, који препорађа и обнавља.

Карактеристике смеховног начела карневала захтевају изоштрене ситуације, чија искошеност стоји насупрот официјелном погледу. Можемо их обухватити појмом скандала, који се тумачи и као најбржи начин трансформације смешног у озбиљно и обрнуто (Микић 1988: 117). Скандалозна ситуација обликује песму „Ловац и лав”, у којој дрски лав глоцка нокте и чарапе заспалог ловца (Радовић 2006: 165). Телесно доле прате и друге стратегије - именовање делова тела, увреде, туча, необични епитети, поигравање лексичким нивоима, да би се пословична сентенца о егзистенцијалним напорима, уместо у финалном, нашла у медијалном сегменту: „У животу није тешко мрети, / ал живети - већ је тежа ствар!” Она није само разградила структуру песме, захтевајући наставак, већ је и оксиморонском антитезом довела у питање уобичајени начин мишљења и из обрнуте перспективе напипала истински проблем. Карневалско понашање захтева фамилијарност, која није страна ни детету. У првом је случају посреди одбацивање друштвене хијерархије и норми пристојности, а у другом више емоционалност као преовлађујућа одлика детињства. Гвидо Тартаља је песник топлих породичних односа, посредованих из неочекиваног угла. У песми „Велика породица” на тематском плану прати се привидно реалистичка представа велике породице, састављене од пет ћеркица и четири сина. Мали лирски субјект измаштава идеалну породицу, а замишља је карневалски маскирану у чету војника (Тартаља 1974: 70). Да је посреди измишљање сигнализира хипербола, која најпре стварност преувеличава по законима дечје жеље, да би се и имагинирано даље имагинирало према законима дечје игре. Реалитет је посредством два нивоа имагинарног отклона обликован као игра. Дете живи у свом, паралелном измишљеном свету, игриво обликованом по обрасцима његовог искуства тако да наликује детињству, али карневалски претераних размера тако да наликује усијаним жељама малишана. И тај је свет његова стварност. 
Дете тежи да свет поистовети са собом, да га доживи као близак и присан, те да га на тај начин сазнаје и прихвата. Зато се и он нуди детету и отвара му се на начин близак њему. У Тешићевој песми „Жетеоци, добар дан” читава се природа понаша по карневалском обрасцу: „Жетеоци, добар дан! / Је ли зрео јечам ран? // Жут к’о дукат, сасвим зрео, / већ је њега голуб јео. / Над столом му свитац сјао / док је слатко вечерао" (Момчило Тешић 1989: 33). Мами гозбеним сликама.

Материјално-телесно начело и гротеска су доминантно облици карневалског дискурса (Бечановић, Николић 2007: 268). Гротеска се тумачи и као сусрет човека са светом, а чин једења и пијења, те мотив отворених уста, као стапање људског тела и света. И не само уста. Неправилни облици, истурени и удубљени делови тела места су њиховог сусрета. Места стварања космичког тела често су обликована помоћу телесног доле и средствима из доњег стилског регистра. Ршумовић у песми „У прашуми у тој збрци” одузима сав понос животињама: „У прашуми у тој збрци / Нестали су лаву брци [...] Пре но шшто је ђипио / Неко му их здипио // У прашуми у русвају / Кљун сломили папагају [...] Сад не може ни да кљује / Ни да виче ни да псује”. Карневалско ругање губитнику, пропраћено поигравањем лексичких нивоа, не доводи у питање истинитост ове ујдурме све док није „у том лому / Реп нестао једном сому". Све док апсурд са становишта логике света песме није изокренуо и њен смисао (Ршумовић 1979: 57-58). За разлику од касније концепције по којој гротеска добија примарно негативну конотацију (Кајзер 2004), карневализација истиче њену амбивалентност и потенцијал обнављања. Душан Радовић је мајстор препородитељске гротеске. У песми „Тежак случај” Стојадин, с надимком Столе, рођен је огроман, па још наопачке. По себи се разуме да таквом диву припадају и огромне количине хране. Логика гротеске у опозицији је с поретком реалности, која упозорава на претеривање, али карневалски амбивалентном поругом-похвалом, што целини текста даје двоструки смисао. Песма се може пратити на линији бенигног подсмеха дечјој машти и свести о њеној нужности, али и као поигравање на ивици два реда тако да се предност не даје ниједном, а свет обликује у његовој трансформативности и колебљивости (Радовић 2006: 205). Својство је гротеске да отвара другачији поглед на стварност. Она је поглед искоса (Пијановић 2001: 119), и искључује нас из реално могућег (Проп 1984: 82). У том се смеру може тражити њена функција у књижевности намењеној најмлађима.

Несвакидашње смешне ситуације подразумевају јунака помереног из уобичајеног лежишта, смешног јунака. Комични ликови морају бити гори него што смо ми и не смеју изазивати саосећање (Аристотел 1977: 9-13). Иако је извео прави подвиг, не изазива га ни змај из истоимене Ршумовићеве песме (Ршумовић 1979: 51-52). Како су се чудом пословично вредни Сремци улењили, Змај је сам покосио сав обилат род: „Змај је косио и косио / И косио док није крепао [...] СРЦЕ МУ ЈЕ ПУКЛО ОД ЖЕЉЕ / ДА БУДЕ НАЈБОљИ КОСАЦ У СРЕМУ”. Трагикомични обрт песме припада карневалском мотиву смешне смрти, а стратегије овог типа очитују се и поигравањем с језиком. Парадигма овог аспекта карневалских стратегија јесте лик сеоске луде, која, 
будући биће с оне стране разума, измиче рационалности и социјалним односима, омогућујући другачије увиде у стварност. Оличена је у Раичковићевом Немањи, лику истоимене песме. Сиромашни, неми и ћосави Немања, „са главом голом и жутом као диња”, иако сам и без игде ичега, безбрижан је и срећан. Неоптерећен имањем, Немања је сама експлозија животности и животне радости (Раичковић 1988: 341). Детињство, као феномен издвојен у односу на свет одраслих и његове намете, промовише своје, веселе вредности и законе.

Преоблачење, маске, двојници припадају сфери игре, која је стални пратилац и карневала и детињства. Чест моменат у делима за најмлађе јесте дете које измишља да је неко други, а готово је већ топос дечак који се игра војника. Такав је неустрашиви дечак из Змајеве песме „Наш јунак”. Лик је обликован колико хиперболом те карневалски хуморном применом идиома и туђица, толико и типичном похвалом-поругом. Дечаково је копље оклагија, а да би био виши, пење се на аван. Финални исказ песме руга се дечјем незнању језика те га карневалски разлаже на делове: „Ко га пита, одговара: 'Ја сам аван-гарда!"' (Змај 1989: 58-59) Већ сама дефиниција карневала: временско-просторна омеђеност и управљање према посебним правилима, упућује на игру (Хојзинга 1970; Кајоа 1979). Особеност карневалске игре је њено изједначавање са стварношћу. За време трајања карневала укида се „рампа”, бришу се разлике између учесника и посматрача и сви заједно живе игру. Она је блиска и свету детињства будући да је за дете вид постојања, активност посредством које оно комуницира и са светом око себе и са самим собом. Због свог изузетног развојног значаја игра је једна од најпрепознатљивијих одлика детињства (Јерковић, Зотовић 2010) па самим тим и књижевности за децу. За време карневала, као и у свету детињства, и сам се живот игра. Парадигма овог аспекта карневала јесте Кочина чигра: „Као реп од љуте змије, / Као ретки цвет од палме, / Као шара турске чалме, / Као пчела која зуји, / Поветарац који хуји, / Брзи поток који струји, / Вртела се, мењала се, / Опчарана, понесена, / Залуђена, занесена" (Вучо 1963: 75). Окреће се у свим бојама и облицима света гурајући и њега у веселу карневалску поворку. Игра је велика стваралачка шанса овог типа писма (Пражић 1971: 10), а његови лудички видови готово су непрегледни.

Карневал је празник везан за време. Он зауставља тренутак у коме живот прелази у смрт и смрт у живот, руши старо да би створио ново, укида коначност и усмерава се ка будућности. Књижевност за децу преводи његове конкретне слике на појмове блиске дечјем искуству. Такви су и стихови интерполирани у причу „Теткини помагачи”: „Дуни, ветре, дуни, / у велике мехове, / па разгори гранчице / грабове и лескове. / Дуни, ветре, дуни, / у церове ломаче, / да се пећи загреју, / да се пеку погаче. // Дуни, ветре, дуни, / кроз димњаке, жлебове, / да се пећи загреју, / да испеку хлебове.” Настала на искуствима народне лирике, песма целокупност света ходом надоле трансформише у гозбу. И то: гозбу у настајању (Максимовић 1961: 92). Званични празник и учвршћује постојећи поредак, појачава његову стабилност, његову хијерархију, вредности, норме, за разлику од карневала који је (бар привре- 
мено) ослобађање од усвојеног реда и владајуће истине, празник настајања, смењивања, обнављања. Против сваког овековечења, завршетка и краја, окренут је будућности која се не завршава. Онако како је и детињство светковина настајања. Песма „Хајде да растемо”, позива: соколице и делије, доколиће, јуначине, хајдевије, хајдуке, хајдетиће, јуначине. Ритмичним, весело алогичним каталогом позива их да расту, да расту до краја: „до последњег милиметра", у који се логиком апсурда и изокретања сакупља метонимијски отеловљен - да детету буде близак - низ људских стремљења (Ршумовић 1979: 7-8). Празнично осећање света Бахтин види као могућност да се превазиђе песимистичка концепција нихилизма, што га доводи у непосредну везу са схватањем наивности у књижевности за децу, с одбацивањем великих претензија на вечне истине, на суморне увиде, с непосредним урањањем у само, голо постојање и потврдом непатвореног тренутка живота и света (Данојлић 1976). Смешно може и да кривотвори суд стварности (Женет 2002: 206). Ако је цела „одрасла” књижевност озбиљна, суморна, иронична, она намењена деци, колико и карневал, весела је потврда постојања. Утолико су и однос према свету. Смешнога нема без света идеја, а хумор има нечег научничког, док је хумориста моралиста који се прерушава у научника, слично анатому који сецира леш само зато да нам га огади (Бергсон 1993: 68). Хумор карневала и књижевности за децу сецира, изобличава, али и поново саставља свет у његову изокренуту, празнично веселу слику у огледалу. Разигране и насмејане карневалске стратегије обликују покрет променљивих, игривих облика, динамичност обнове. Колико и игра, и карневал је велика стваралачка шанса књижевности за децу.

\section{ЛИТЕРАТУРА}

Аристотел 1977: Aristotel, Nauk o pjesničkom umijeću, Zagreb: SCS.

Бахтин 1978: M. Bahtin, Stvaralaštvo Fransoa Rablea i narodna kultura srednjega veka i renesanse, Beograd: Nolit.

Бергсон 1993: A. Bergson, Smeh: esej o značenju komičnog, Beograd: Lapis.

Бечановић Николић 2007: 3. Бечановић-Николић, Бахтин и тумачење Шекспирових историјских драма: карневализација и хетороглосија, $y$ : Ј. Делић (ур.), Нови Сад, Зборник Матице српске за књижевност и језик, год. 55, бр. 2 , 265-288.

Бошковић 2008: Д. Бошковић, Поступак карневализације у роману Херој на магариу Миодрага Булатовића, Панчево: Свеске, XIX/ 90, 91-97.

Витез 1986: Г. Витез, Непослушне ствари, Сарајево: „Веселин Маслеша”.

Вучо 1963: А. Вучо, Сан и јава храброг Коче, Београд: Просвета.

Данојлић 1974: M. Danojlić, Kako spavaju tramvaji, Sarajevo: „Veselin Masleša”. Данојлић 1976: М. Данојлић, Наивна песма, Београд: Нолит.

Енглблом 2007: F. Englblom, Mnogostrukost glasova: karnevalizacija i dijalogičnost u romanima Salmana Ruždija, Novi Sad: Polja, LII/448, 40-49. 
Женет 2002: Ž. Ženet, Figure, Novi Sad: Svetovi.

Змај J. 1989: Ј. Змај, Дечје песме, Одабрана дела Јована Јовановића Змаја, Књига VI, Нови Сад: Матица српска.

Јерковић, Зотовић 2010: И. Јерковић - М. Зотовић, Развојна психологија, Нови Сад: Филозофски факултет, Универзитет у Новом Саду

Kajzep 2004: V. Kajzer, Groteskno u slikarstvu i pesništvu, Novi Sad: Svetovi.

Kajoa 1979: Rože Kajoa, Igre i ljudi, Beograd: Nolit.

Капичић Хаџић 1979: N. Kapičić Hadžić, „Pjesma-igra Dušna Radovića”, Od Zmaja do Viteza, Sarajevo: Zavod za izdavanje udžbenika.

Коменски 1967: J. А. Коменски, Велика дидактика, Београд: Завод за издавање уџбеника СР Србије.

Крамбергер 2009: Марјан Крамбергер, Позитивна онтологија детињства, $y$ : Ј. Љуштановић (прир.), Приниеза лута замком, Нови Сад: Змајеве дечје игре, 31-33.

Курцијус 1971: E. R. Curtius, Evropska književnost i latinsko srednjovjekovlje, Zagreb: Matica hrvatska.

Лукић 1962: Д. Лукић, Мој тролејбус, Београд: Просвета.

Љуштановић 2004: Ј. Љуштановић, Црвенкапа грицка вука, Нови Сад: ДОО Дневник - Новине и часописи - Змајеве дечје игре.

Максимовић 1961: Д. Максимовић, Ако је веровати мојој баки, Београд: Младо поколење.

Марковић 1991: С. Ж. Марковић, Записи о књижевности за деиу, Београд: Научна књига.

Микић 1988: Р. Микић, Поступак карневализащије: Увод у поетику Ранка Маринковића, Београд: „Филип Вишњић”.

Пијаже, Инхелдер 1978: Ж. Пијаже, Б. Инхелдер, Интелектуални развој детета, Београд: ЗУНС.

Пијановић 2001: П. Пијановић, Поетика гротеске, Београд: Народна књига-Алфа.

Потић 2010: Д. Потић, Загонетка у Раичковићевом стваралаштву за децу, Нови Сад: Детиюствво, XXXV/4, 87-98.

Потић 2010а: Д. Потић, Карневал под сунцем, Карневализација слике детињства у књижевности за децу Стевана Раичковића, Нови Сад: Детињство, XXXVII/ 3, 3-17.

Потић 2014: Д. Потић, Језик и маске, $y$ : В. Јовановић, Т. Росић (ур.), Књижевност за деиу у науции и настави, Јагодина: Факултет педагошких наука у Јагодини, 203-222.

Потић 2015: Д. Потић, У преображају свет, Имагинативни лудизам у поезији за децу Стевана Раичковића, $y$ : Д. Видановић (ур.), Зборник радова високе школе струковних студија за образовање васпитача у Пироту, Пирот: Висока школа струковних студија за образовање васпитача у Пироту, 158-171.

Потић, Јовановић 2013: Д. М. Потић, В. П. Јовановић, Игра ироније Душана Радовића, y: Ј. Делић (ур.), Зборник матице српске за књижевност и језик, LXI/1, Нови Сад: Матица српска, 227-239. 
Пражић 1971: M. Pražić, Igra kao sloboda, Novi Sad: Zmajeve dečje igre - Kulturni centar.

Прелевић 1979: R. Prelević, Poetika dečje književnosti, Mostar: Prva književna komuna.

Проп 1984: V. Prop, Problemi komike i smeha, Novi Sad: Dnevnik - Književna zajednica Novog Sada.

Радовић 2006: Д. Радовић, Баш свашта, Сабрани списи, Београд: ЗУНС.

Раичковић 1998: С. Раичковић, Сабрана дела, књига 5, Београд: ЗУНСБИГЗ-СКЗ.

Ристивојевић 2009: M. Ristivojević, Bahtin o karnevalu, Београд: Etnoantroploški problemi, IV/3, 197-210.

Ршумовић 1979: Љ. Ршумовић, Хајде да растемо, Београд: Нолит - Просвета - Завод за уџбенике.

Самарџија 2004: С. Самарџија, Пародија у усменој къижевности, Београд: Народна књига - Алфа.

Тартаља 1974: Г. Тартаља, Сјатиле се песме, Београд: СКЗ.

Тешић 1989: М. Тешић, Шта ко жели и сања, Београд: Нолит.

Ћопић 1968: B. Ćopić, Pjesme, Pjesme pionirke, Sabrana dela Branka Ćopića, knjiga osma, Beograd-Sarajevo: Prosveta-Svjetlost-,,Veselin Masleša”.

Хант 2013: П. Хант, Увод: изучавање света књижевности за децу, $y:$ П. Хант, Тумачење књижевности за деиу, Београд: Учитељски факултет у Београду, 7-26.

Хојзинга 1970: J. Huisinga, Homo ludens, Zagreb: Matica hrvatska.

Цар-Михец 1993: A. Car-Mihec, Menipejska tradicija i dramsko stvaralaštvo A. Strindberga, Rijeka: Fluminensia, V/1-2, 71-81.

Црнчевић 1963: Б. Црнчевић, Босоноги и небо, Београд: Просвета.

Dušica M. Potić

CARNIVALIZATION OF THE WORLD MODEL IN CHILDREN'S LITERATURE

(Summary)

Carnival is a street folk festivity associated with time. It manifests itself in three forms: performing ritual forms, humorous and parody literary works, as well as various forms and genres of a free street speech. Strategies of carnivalization in literature encompass all three aspects. In this paper the author shall focus on general principles of a carnivalization of the world model in Serbian children's poetry, which implies embracing ready-made patterns as well as modifying and adapting them. Thus, the author shall devote her attention to Serbian poets for children. 